\title{
Perunan GM-lajikkeiden jääntimukulat - riski geeniaineksen siirtymisestä.
}

\author{
Leo Mustonen ${ }^{1)}$, Pirjo Peltonen-Sainio ${ }^{1)}$ ja Katri Pahkala ${ }^{1)}$ \\ ${ }^{1)}$ Maa- ja elintarviketalouden tutkimuskeskus, Kasvintuotannon tutkimus, 31600 Jokioinen, www.mtt.fi
}

\section{Tiivistelmä}

Peruna on rapsin rinnalla todennäköisin geenimuunneltu viljelykasvimme. Kun perunan tuotanto on alueellisesti keskittynyt Satakuntaan ja Pohjanmaan rannikkoalueille, muuntogeenistä perunaa joudutaan tulevaisuudessa viljelemään rinnakkain tavanomaisen perunan kanssa. Perunan muuntogeenisiä lajikkeita viljeltäessä on otettava huomioon tavanomaisten ja geenimuunneltujen lajikkeiden rinnakkaiselo. Muunneltua geeniainesta ei saa siirtyä tavanomaiseen perunan viljelyyn. Lajikkeiden sekoittuminen voi tapahtua siemeneriä siirreltäessä tai koneiden mukana. Toinen merkittävä riski ovat perunan korjuussa maahan jäävät mukulat ja niistä kasvavat jääntikasvit, joiden mukulat voivat sekoittua tavanomaisesti viljeltyyn perunaan. Maahan jäävä mukulamäärä voi olla suuri, jopa 20 000-40 000 kpl/ha. Mahdollinen riskitekijä geeniaineksen siirtymisessä on myös perunan botaaninen siemen. Perunan sukulaiskasvit mustakoiso (Solanum nigrum) ja punakoiso (Solanum dulcamara) eivät risteydy perunan kanssa eikä muuntogeenien leviäminen rikkakasvien kautta ole mahdollista.

Gm-perunan viljely Euroopassa tullaan aloittamaan muuntogeenisten tärkkelysperunalajikkeiden viljelyllä. EU:ssa on parhaillaan käsiteltävänä hakemus Ruotsissa jalostetun muuntogeenisen Amflora-lajikkeen hyväksymiseksi viljelyyn. Lajike on entinen Prevalent-lajike, josta on kehitetty geenimuuntelun avulla tärkkelyksen koostumukselta poikkeava amylopektiinimuoto. Suomessa on kokeissa kotimaisia korkean tärkkelyspitoisuuden omaavia koelinjoja. Muualla kuin EU-alueella viljellään pienessä mitassa koloradokuoriaisenkestävää geenimuunneltua perunaa.

Korjuussa maahan jäävät perunat tuhoutuvat talven aikana, jos lämpötila laskee useiden kuukausien ajaksi -1,0 ${ }^{\circ} \mathrm{C}$ alemmaksi. Pitkä kylmyysjakso lähellä jäätymisrajaa kuluttaa perunan liukoiset sokerit ja peruna tuhoutuu. Erillisissä kylmänkestävyyskokeissa kolmasosa mukuloista tuhoutui, kun lämpötila oli kahden vuorokauden ajan -2,0 - -2,5 ${ }^{\circ} \mathrm{C}$. Kun lämpötila pidettiin 3-4 vuorokauden ajan $-3,0--3,5^{\circ} \mathrm{C}$ perunat tuhoutuivat täydellisesti. Lajikkeista Asterix osoittautui suuremman sokeripitoisuutensa ansiosta selvästi Saturnaa kestävämmäksi. Samasta syystä myös pieni mukulakoko (30 mm) oli suurta mukulakokoa (50 mm) kestävämpi. Perunan tärkeimmällä viljelyalueella Pohjanlahden rannikolla lumikerros jää useimpina talvina ohueksi ja jääntimukulat tuhoutuvat maan routaantuessa. Riski jääntimukuloiden säilymisestä lisääntyy, kun pysyvä lumipeite tulee ennen maan routaantumista. Botaaninen siemen ja siitä kasvava peruna eivät ole merkittävä riskitekijä tavanomaisen ja geenimuunnellun perunan rinnakkaiselossa. Muuntogeenisen lajikkeen siementen muodostuminen voidaan estää jalostamalla muuntogeenisistä lajikkeista koirassteriilejä.

Jääntiperunan säilyminen maassa on mahdollista mallintaa maan lämpötilan perusteella ja laatia talven ilmastotietojen perusteella ennuste gm-perunan säilymisriskeistä eri osissa maata.

Asiasanat: gm-peruna, gm-perunalajikkeet , jääntimukulat, perunan kylmänkestävyys 


\section{Johdanto}

Peruna on rapsin rinnalla todennäköisin geenimuunneltu tulevaisuuden viljelykasvimme. Kun perunan tuotanto on alueellisesti keskittynyt Satakuntaan ja Pohjanmaan rannikkoalueille, muuntogeenistä perunaa joudutaan tulevaisuudessa viljelemään rinnakkain tavanomaisen perunan kanssa. Perunan muuntogeenisiä lajikkeita viljeltäessä on otettava huomioon tavanomaisten ja geenimuunneltujen lajikkeiden rinnakkaiselo. Muunneltua geeniainesta ei saa siirtyä tavanomaiseen perunan viljelyyn. Lajikkeiden sekoittuminen voi tapahtua siemeneriä siirreltäessä tai koneiden mukana. Toinen merkittävän riski ovat perunan korjuussa maahan jäävät mukulat ja niistä kasvavat jääntikasvit, joiden mukulat voivat sekoittua tavanomaisesti viljeltyyn perunaan. Nostossa perunasta jää maahan pienin mukulakoko ja satunnaisesti suurempia mukuloita. Maahan jäävä mukulamäärä voi olla hyvin suuri, jopa 20 000-40 000 kpl/ha. Mahdollinen riskitekijä geeniaineksen siirtymisessä voi olla myös perunan botaaninen siemen, joskin siemenestä kasvavan perunan kilpailukyky on jääntimukuloita heikompi. Geenien siirtyminen perunasta sen sukulaislajeihin on Suomessa hyvin epätodennäköistä. Perunan sukulaiskasvit mustakoiso (Solanum nigrum) ja punakoiso (Solanum dulcamara) eivät risteydy perunan kanssa eikä muuntogeenien leviäminen rikkakasvien kautta ole mahdollista.

Gm-perunan viljely Euroopassa tullaan aloittamaan muuntogeenisten tärkkelysperunalajikkeiden viljelyllä. EU:ssa on parhaillaan käsiteltävänä hakemus Ruotsissa jalostetun muuntogeenisen Amflora-lajikkeen hyväksymiseksi viljelyyn. Lajike on entinen Prevalent-lajike, josta on kehitetty geenimuuntelun avulla tärkkelyksen koostumukselta poikkeava amylopektiinimuoto. Lajike on ollut EU.n lajikehyväksyntää varten kokeissa vuodesta 1993 alkaen. Amflora tullaan hyväksymään viljelyyn vuoden 2008 aikana lähinnä paperiteollisuuden eritystarpeisiin. Suomessa on kokeissa kotimaisia korkean tärkkelyspitoisuuden omaavia koelinjoja, jotka on tarkoitettu tärkkelysteollisuuden käyttöön. Muualla kuin EU-alueella viljellään pienessä mitassa koloradokuoriaisenkestävää geenimuunneltua perunaa mm. Venäjällä ja Yhdysvalloissa. Myös EU:ssa on testattavana eri tarkoituksiin jalostettuja muuntogeenisiä lajikkeita. Kokeissa on useissa maissa esimerkiksi täysin rutonkestäviä lajikkeita, joihin on siirretty kestävyysgeenejä villiperunalajeista.

\section{Aineisto ja menetelmät}

Esgemo-tutkimusohjelmassa selvitettiin Jokioisissa vuosina 2004-2007 muuntogeenisen ja tavanomaisen perunan rinnakkaiselon riskejä sekä suosituksia toimenpiteiksi ja ehdotuksiksi, jotka estävät muunnellun geeniaineksen siirtymisen tavanomaiseen viljelyyn. Kenttäkokeissa tutkittiin perunan jääntimukuloiden säilymistä maassa talven aikana. Kokeet perustettiin syksyllä perunan korjuun jälkeen perunan viljelyyn soveltuvalle kevyelle hietamaalle. Koetekijöinä olivat lajike, mukulan vararavinnon määrä (mukulakoko 30 ja 50 $\mathrm{mm})$ ja mukuloiden syvyys maassa $(10$ ja $20 \mathrm{~cm})$. Haluttiin selvittää perunalajikkeiden geneettisestä taustasta johtuvat erot, kuten tärkkelyspitoisuuden vaikutus ja kyky muodostaa sokereita alhaisissa lämpötiloissa. Lajikkeet olivat tärkkelysperuna Saturna ja ruokaperuna Asterix. Kokeessa pyrittiin selvittämään maan lämpötilan raja-arvot, joissa peruna säilyy talven ajan elinkykyisenä. Pellolla tehtyjen kokeiden täydentämiseksi tehtiin myös kylmyydenkestävyyskokeita, joissa selvitettiin mukuloiden tuhoutuminen $-2,0--5,0{ }^{\circ} \mathrm{C}$ lämpötiloissa. Kokeissa selvitettiin lajikkeen ja mukulakoon vaikutusta sekä lämpötila-arvoja, joissa peruna jäätyessään tuhoutuu. Kokeiden yhteydessä tehtiin selvitys Saturna-lajikkeen botaanisesta siemenestä kehittyvien siementainten kasvusta ja mukuloiden tuottokyvystä sekä mahdollisista riskeistä.

\section{Tulokset ja tulosten tarkastelu}

Kolmena koevuotena 2004-2007 talven sää- ja lämpötila sekä pysyvän lumen tulonajankohta vaihtelivat suuresti ja vaikuttivat ratkaisevasti jääntiperunan säilymiseen maassa. Erityisesti pysyvän lumentulon ajankohta sekä lumen paksuus vaikuttavat maan routaantumiseen ja perunan säilymiseen. Ilmava lumikerros estää ja hidastaa ankarankin pakkasen etenemisen ja maan routaantumisen. Talvikautena 2004-2005 maan lämpötila laski helmi-maaliskuun pakkaskauden aikana -0,1- $-0,2{ }^{\circ} \mathrm{C}$ tasolta nopeasti aina $-4,0--6,2{ }^{\circ} \mathrm{C}$. Kaikki jääntimukulat tuhoutuivat täydellisesti. Merkittävin tekijä lämpötilan laskuun oli ohut $10-15 \mathrm{~cm}$ lumikerros. Talvikautena 2005-2006 maan lämpötila laski 10 cm syvyydessä joulukuun puolivälin tienoilla nollan tasolle ja oli alimmillaan helmikuun lopussa $-0,9$. Vastaavasti $20 \mathrm{~cm}$ syvyydessä lämpötila laski pakkaselle tammikuun lopussa ja oli alimmillaan maaliskuun puolivälissä $-0,4{ }^{\circ} \mathrm{C}$. Helmikuussa tullut $35-45 \mathrm{~cm}$ syvyinen lumikerros esti maan jäätymistä myös ankarien pakkasjaksojen aikana. Lämpötilan jääminen lievästi pakkasen puolelle 3-4 kuukauden ajaksi oli kuitenkin perunan elinvoiman ja säilymisen kannalta kriittinen. Jääntiperunoista säilyi 1,4-2,6 \% elinkykyisinä eikä koejäsenten välillä todettu eroja. Talvikautena 20062007 maan lämpötila laski $10 \mathrm{~cm}$ syvyydessä tammikuun lopussa $-5,4{ }^{\circ} \mathrm{C}$ lukemaan. Myös $20 \mathrm{~cm}$ syvyydessä 
lämpötila laski alimmillaan helmikuun lopulla $-2,1{ }^{\circ} \mathrm{C}$. Pitkä pakkasjakso ja alhaiset lämpötilat tuhosivat jääntimukulat. Lämpötilaerot maan pinnassa sekä $10 \mathrm{~cm}$ ja $20 \mathrm{~cm}$ syvyydessä olivat huomattavat. Maan pinnan lämpötila seurasi ulkoilman lämpötilaa. Syvä lumikerros eristi tehokkaasti kylmyyden ja maan pinnan lämpötila pysyi nollan tienoilla myös pakkasjaksojen aikana. Lämpötilaero $10 \mathrm{~cm}$ ja $20 \mathrm{~cm}$ syvyydessä oli talven alkaessa $0,5-1,0{ }^{\circ} \mathrm{C}$ ja suurimmillaan pakkasjaksojen aikana $2,0-4,2{ }^{\circ} \mathrm{C}$.

Pellolla tehtyjen kokeita täydentämään järjestettiin kylmänkestävyyskokeita, joissa testattiin mukuloiden kestävyyttä $-2,0--5,0{ }^{\circ} \mathrm{C}$ lämpötiloissa. Perunan paleltumisrajaa lähellä olevissa lämpötiloissa Asterix osoittautui selvästi Saturnaa kestävämmäksi ja pystyi palautumaan paremmin jäätymisshokista. Syynä Saturnan heikompaan kylmänsietokykyyn on sen pienempi sokeripitoisuus. Suuren sokeripitoisuuden tiedetään suojaavan solukoita jäätymiseltä, jos lämpötila laskee nopeasti. Myös pieni mukulakoko (30 mm) osoittautui kylmänkestävyydeltään lievästi suurta mukulakokoa $(50 \mathrm{~mm})$ paremmaksi. Kestävyys perustuu samalla tavalla pienen mukulakoon suurempaan sokeripitoisuuteen. Perunan jäätyminen alkaa, kun lämpötila on noin kahden vuorokauden ajan $-2,0--2,5^{\circ} \mathrm{C}$, jolloin 30-40 \% mukuloista tuhoutuu. Kaikki perunat eivät tuhoudu, koska yksittäisten mukuloiden koostumus poikkeaa toisistaan. Kun lämpötila pidettiin 3-4 vuorokauden ajan $-3,0--3,5^{\circ} \mathrm{C}$ jokainen peruna jäätyi ja tuhoutui täydellisesti.

Osa perunalajikkeista, kuten Saturna, muodostaa runsaasti botaanista siementä, joka säilyy itämiskykyisenä useita vuosia. Siementainten kilpailukyky on siemenperunasta kasvavaan perunaan verrattuna heikko, mutta avoviljelyssä siementaimet tuottavat mukuloita. Kun koeolosuhteissa viljeltiin Saturnaa havaittiin seuraavana kasvukautena 3-7 siementainta $100 \mathrm{~m}^{2}$, jotka kukin tuottivat 5-12 mukulaa. Botaaninen siemen ja siitä kasvava peruna ei ole merkittävä riskitekijä tavanomaisen ja geenimuunnellun perunan rinnakkain viljelyssä. Muuntogeenisen lajikkeen siementen muodostuminen voidaan tarvittaessa myös estää jalostamalla muuntogeenisistä lajikkeista koirassteriilejä.

\section{Johtopäätökset}

Korjuussa maahan jäävät perunat tuhoutuvat talven aikana, jos lämpötila laskee useiden kuukausien ajaksi $-1,0^{\circ} \mathrm{C}$ alemmaksi. Pitkä kylmyysjakso lähellä jäätymisrajaa kuluttaa perunan liukoiset sokerit loppuun ja mukulat tuhoutuvat. Erillisissä kylmänkestävyyskokeissa kolmasosa mukuloista tuhoutui, kun lämpötila oli kahden vuorokauden ajan -2,0 - -2,5 ${ }^{\circ} \mathrm{C}$. Kun lämpötila pidettiin 3-4 vuorokauden ajan $-3,0--3,5^{\circ} \mathrm{C}$ perunat jäätyivät ja tuhoutuivat täydellisesti. Lajikkeista Asterix osoittautui suuremman sokeripitoisuutensa ansiosta selvästi Saturnaa kestävämmäksi. Samasta syystä myös pieni mukulakoko (30 mm) oli suurta mukulakokoa (50 mm) kestävämpi. Erityisesti pysyvän lumentulon ajankohta sekä lumen syvyys vaikuttavat maan routaantumiseen ja perunan säilymiseen. Perunan tärkeimmillä viljelyalueilla Pohjanlahden rannikkoalueilla ja Etelä-Pohjanmaalla lumikerros jää useimpina talvina ohueksi ja jääntimukulat tuhoutuvat maan routaantuessa. Riski jääntimukuloiden säilymisestä lisääntyy, kun pysyvä lumipeite tulee ennen maan routaantumista. Botaaninen siemen ja siitä kasvava peruna ei ole merkittävä riskitekijä tavanomaisen ja geenimuunnellun perunan rinnakkainelossa. Muuntogeenisen lajikkeen siementen muodostuminen voidaan tarvittaessa estää jalostamalla muuntogeenisistä lajikkeista koirassteriilejä. Jääntiperunan säilyminen maassa on mahdollista mallintaa maan lämpötilan raja-arvojen perusteella ja laatia talven ilmastotietojen perusteella ennuste gmperunan säilymisriskeistä eri osissa maata.

\section{Kirjallisuus}

Lawson, H.M. 1986. Potato seedlings: a review of current situation. Aspects of Appl. Biology 13:187-194

Lumkes, L.M. 1981. EAPR working group ' Volunteer potatoes'. Potato Research 24: 448-449.

Lutman, P.J.W. 1976. Investigations into some aspects of the biology of potatoes as weeds. Weed Research.17:123-132.

Malone, J.G., Mittova, V., Ratcliffe, G. \& Kruger, N.J. 2006. The response of carbohydrate metabolism in potato tubers to low temperature. Plant Cell Physiol. 47: 1309-1322.

MMM. 2005. Muuntogeenisten viljelykasvien sekä tavanomaisen ja luonnonmukaisen maataloustuotannon rinnakkaiselon mahdollistaminen Suomessa. Työryhmämuistio MMM 2005:16.

Pearce, R.S. 2001. Plant freezing and damage. Annals of Botany 87: 417-424. 